\title{
QUANTITATIVE HISTOLOGY OF THE HUMAN GROWTH PLATE
}

\author{
N. F. Kember and H. A. Sissons, London, England
}

From St Bartholomew's Hospital and the Institute of Orthopaedics, Royal National Orthopaedic Hospital, London

This paper describes a study in the human femur of the relationship between cell division in growth cartilage and overall bone growth. Growth rates for the distal femur from birth to eighteen years were determined from serial radiographs available from the Harpenden Growth Study. An average of $1.4 \mathrm{~cm} /$ year was found for the ages of five to eight years. The development of the growth plate is illustrated in a series of photomicrographs of femur sections. These sections were also used for quantitative histology. The length of the proliferation zone was estimated from cell counts to be twenty-four cells per column. On the basis of this value and the measured growth rate, an approximate mean cycle time of twenty days was found for the proliferating cells of the human growth plate. Since the corresponding cycle time is two days for rodent growth plates, which also have a different structure, it is unwise to extrapolate the findings in this tissue from mouse to man.

During the past twenty years considerable advances have been made in understanding the quantitative relationship between cell division in the epiphysial growth plate and the actual rate of longitudinal growth of the bones concerned (Sissons 1971; Kember 1972). This work, however, has been carried out on small laboratory animals, and virtually no information is available on this aspect of the human growth plate (Rang 1969).

The aim of the present study has been to put together what information is available to us on the cell kinetics of longitudinal bone growth in man. At the Institute of Orthopaedics in London, our collection of normal bone material includes histological specimens from a number of children before the cessation of growth. We have concentrated our attention on the histological appearance of the growth plate at the distal end of the femur, partly because this was the one most often available for study, and partly because information on the growth of this part of the skeleton was available to us at the Institute of Child Health as part of Professor Tanner's Harpenden Growth Study (Tanner, Whitehouse and Takaishi 1966).

Because the literature contains so little information on the histological structure of human growth plates, we have felt it justified to accompany our quantitative information by a series of photomicrographs illustrating the development of the growth plate at the distal end of the femur from birth to the cessation of growth.

\section{MATERIAL AND METHODS}

\section{Histology}

Specimens were available from twelve subjects aged from birth to fourteen years of age (Table I.) The femurs were collected at necropsy examination in cases of accident or acute illness, and were available within twenty-four hours of death.
The bones were dissected free from soft tissue and fixed in neutral formalin. Selected blocks of tissue were decalcified in ethylene-diamine-tetra-acetic-acid at neutral $\mathrm{pH}$ : those from the lower end of the femur were oriented longitudinally and were from the centre of the bone in the antero-posterior plane.

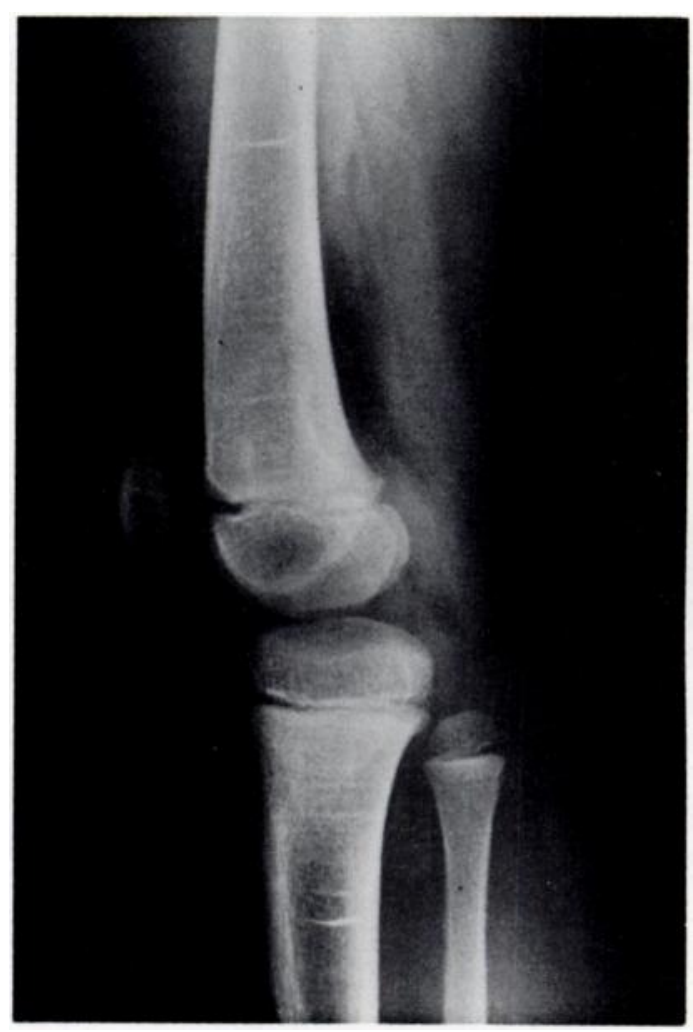

FIG. 1

Radiograph of a knee showing lines of growth arrest.

After decalcification, the blocks were embedded in celloidin; $15 \mu \mathrm{m}$ sections were cut and stained with haematoxylin and eosin. Measurements on the bone blocks and the final sections showed a linear shrinkage of 13 per cent during processing,

N. F. Kember, Ph.D., D.Sc., F.Inst.P., Reader in Physics, The Medical College of St Bartholomew's Hospital, Charterhouse Square, London ECIM 6BQ, England.

Professor H. A. Sissons, M.D., F.R.C.P., F.R.C.S., F.R.C.Path., Department of Morbid Anatomy, The Institute of Orthopaedics, Royal National Orthopaedic Hospital, 234 Great Portland Street, London WIN 6AD, England. 
and this has been allowed for in measurements made on the sections.

The width of the "inert" and "columnar" zones of each growth plate was measured with a calibrated eyepiece graticule. Measurements were made at multiple points across the plate, the direction of growth of the bone. An average value was derived from measurements made on five groups of ten cells selected at regular intervals along the metaphysial border of the growth plate.

The number of cells in the cartilage columns of the growth

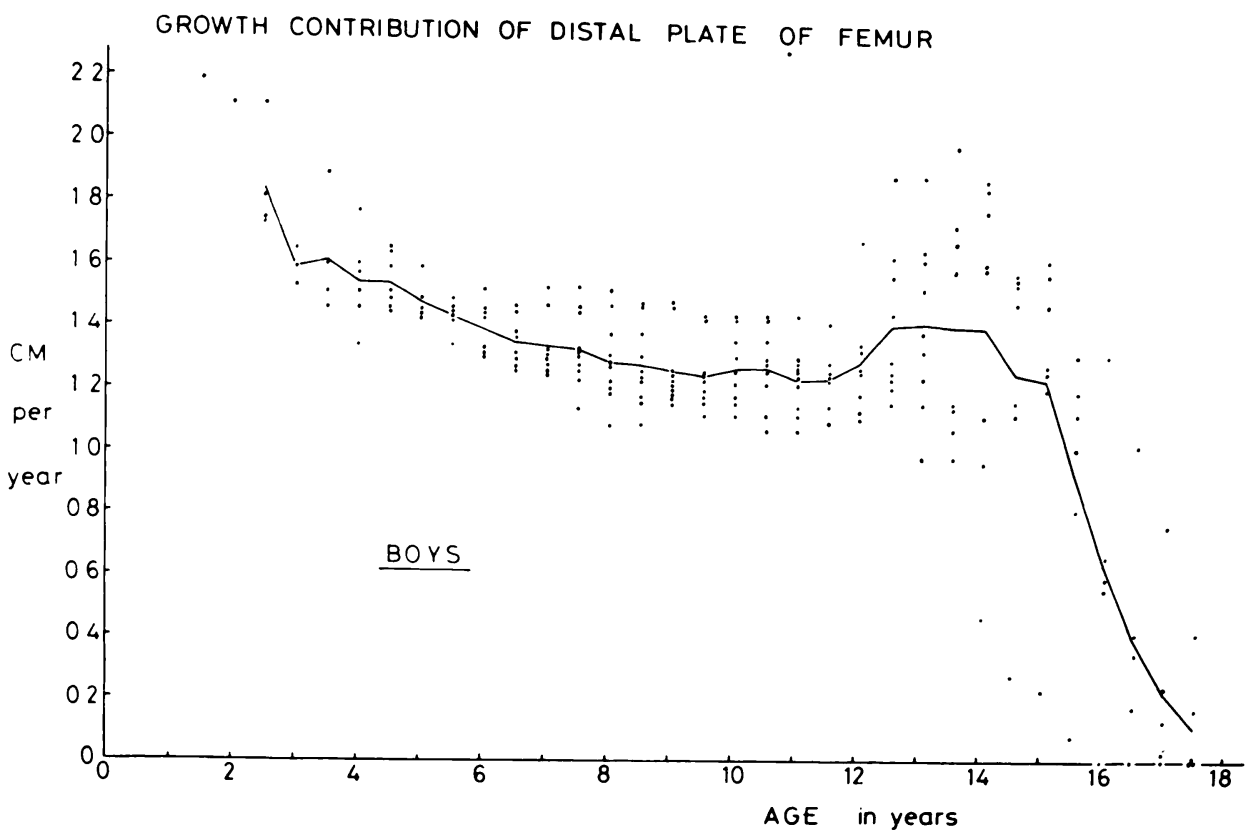

Fig. 2

Longitudinal growth of distal plate of femur in boys. Each point represents a measured growth rate, while the continuous line joins the mean values for each age.

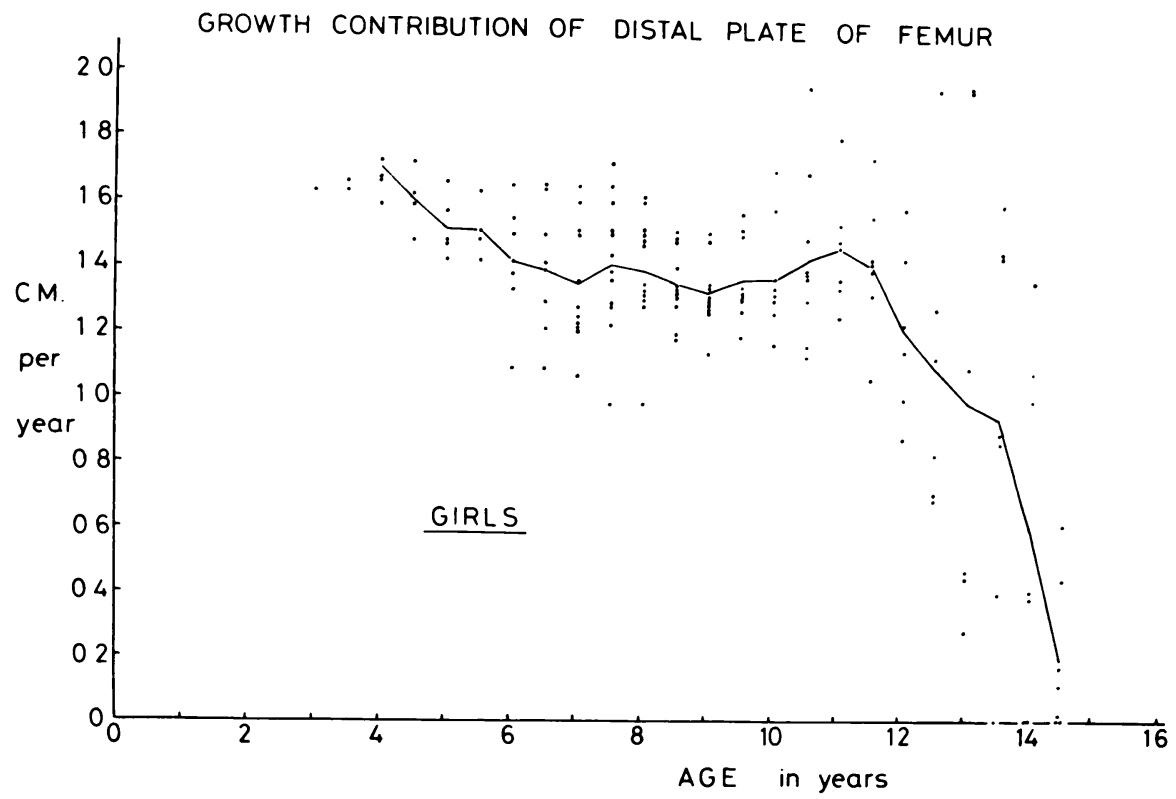

Fig. 3

Longitudinal growth of distal plate of femur in girls.

taking every fiftieth column of cartilage cells as a point for measurement. For most of the specimens, two or more sections were available for this and other types of measurement.

The height of hypertrophic cartilage cells was also measured-that is, the maximum dimension of the cell spaces in plate was also determined. Cell counts were made on approximately every fiftieth column, the number of hypertrophic cells and of the remaining cells of the column (the "maturation" and "proliferation" zones) being recorded separately (Figs. 8 and 11). When a column was interrupted, the cell counts were 
continued in an adjacent column until the last cell in the columnar zone of the cartilage was reached. These cell counts are, to some extent, subjective, and involve decisions about the extent of the columns and the distinction between the hypertrophic and maturation zones of the plates. The criteria adopted were, however, the same as in previous studies on laboratory animals (Kember 1972, 1973), so the results may usefully be compared.

\section{Radiography}

In the Harpenden growth study, lateral radiographs of the knee had been taken at intervals of three or six months in a large series of normal children during the period of growth. These films included the lower end of the femur and the adjacent part of the shaft. Review of the films for the purposes of the present study showed that in some cases (perhaps a quarter of the whole series) transverse lines of growth arrest-Harris's lines (Harris 1933)could be found, as shown in Figure 1. When present,

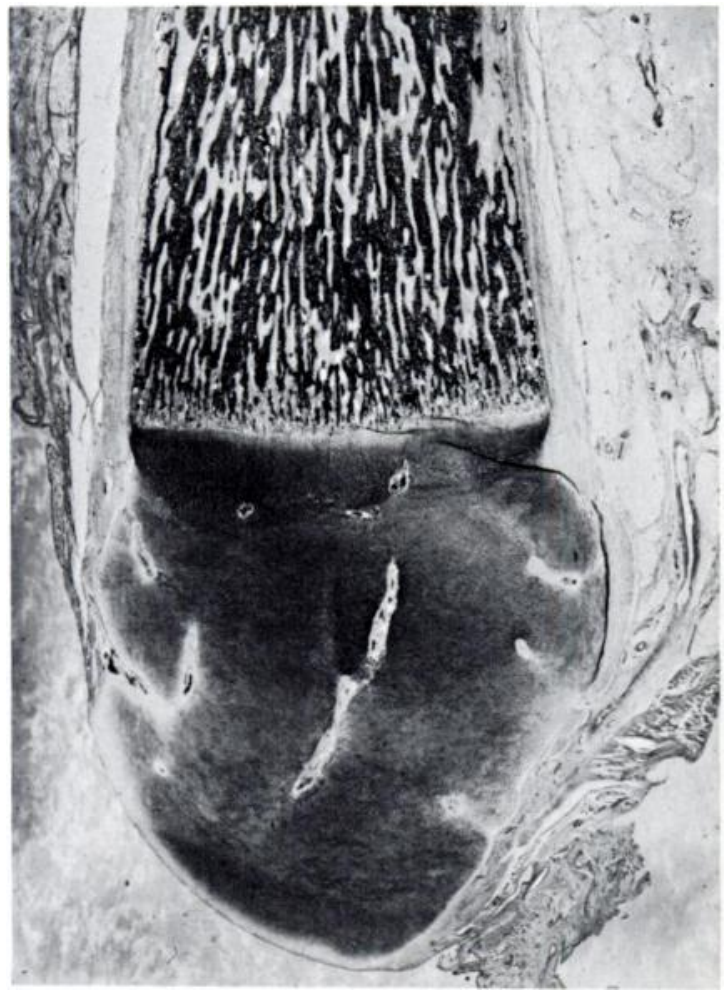

FIG. 4

Male foetus at term. Longitudinal section through lower end of femur. (Haematoxylin and eosin, $\times 4 \cdot 6$.)

these lines usually persisted for a period of some years, and could be traced from one radiograph to the next during this period. This made it possible to use one of the lines as a "marker" for the longitudinal growth occurring at the distal growth plate of the femur, by measuring the distance from the transverse line to the proximal surface of the growth plate. The serial measurements for each child were plotted, and the corresponding values for the longitudinal growth rate were read off at half-yearly intervals on the smoothed curves.
Standardisation of the film-focus and film-knee distances in the original radiographs resulted in a constant magnification factor of 1.04 , and this was allowed for in our measurements.

\section{RESULTS}

Determinations of growth rate

Our results for the rate of longitudinal growth of the distal plate of the femur are shown in Figures 2 and 3. Each point represents a measured rate of growth in one child at one particular age, while the continuous line joins the mean values for each age. Lines of growth arrest were found most often between the ages of six and ten years; as a result it was possible to obtain sufficient growth rate values to provide a reasonably adequate description of the variation over this age range. Below

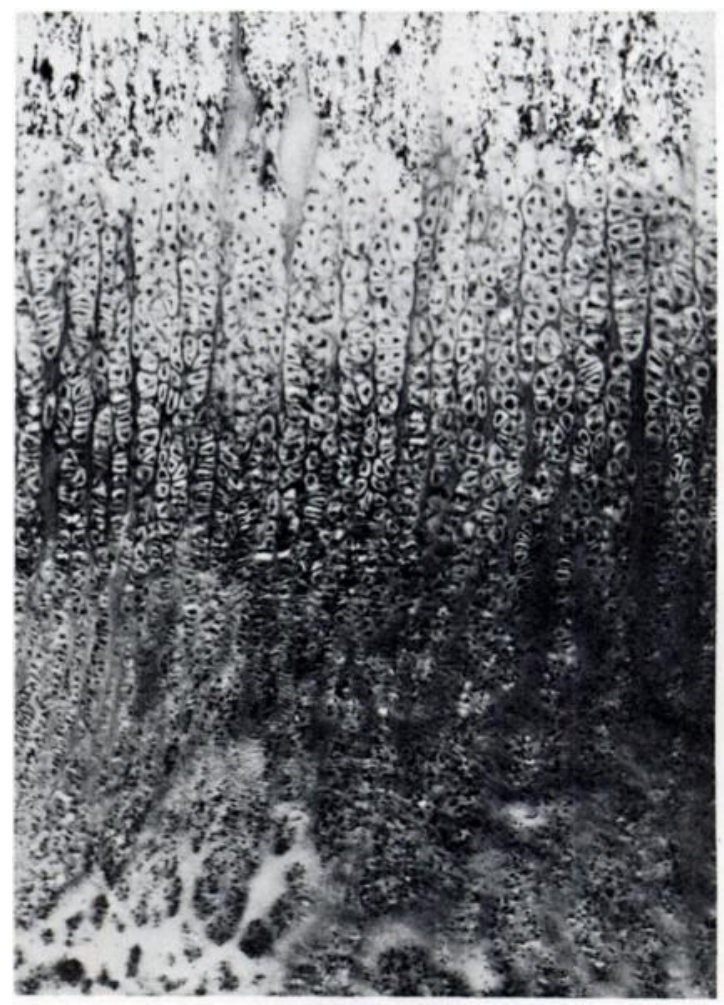

Fig. 5

Male foetus at term. Columnar part of growth cartilage from Figure 4. (Haematoxylin and eosin, $\times 66$.)

four years of age there are relatively few observations, and for ages above ten more observations are needed adequately to define the increased scatter of results during the period-ten to fourteen years for girls, and twelve to seventeen years for boys-in which individuals show their adolescent growth spurt, although the existence of this is apparent in our results. After the adolescent growth spurt, the rate of growth falls dramatically. Before the age of ten there is little difference in the mean values for boys and girls. 
Histology of growth plate

The progressive changes in the histological structure of the distal growth plate of the human femur are illustrated in Figures 4 to 13. At birth, the secondary centre of ossification in the epiphysis is incompletely developed or where cartilage cells are arranged in regular columns (Fig. 7). On the epiphysial aspect of the plate there is a zone where cartilage cells fail to show this columnar arrangement (Fig. 7) but are arranged in small groups or rows that are sometimes oriented perpendicularly to the

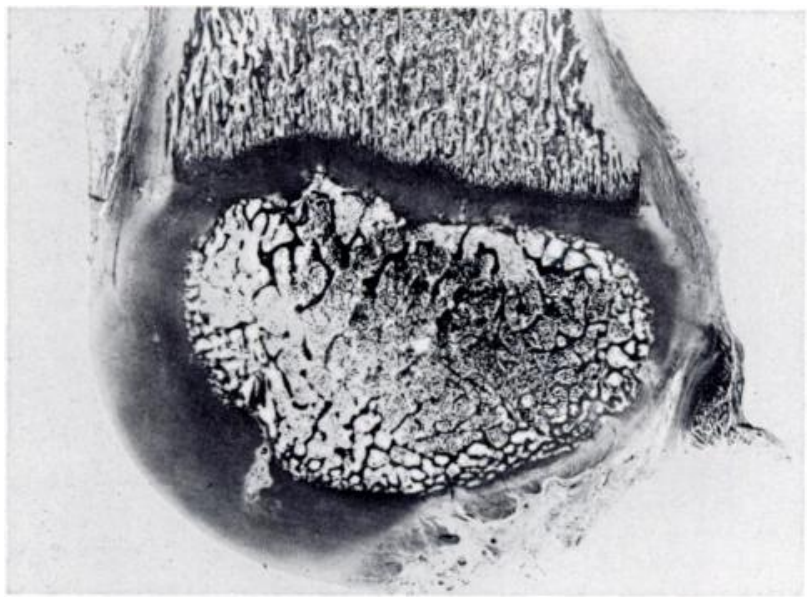

Fig. 6

Female, 16 months. Longitudinal section through lower end of femur. (Haematoxylin and eosin, $\times 3 \cdot 75$.)

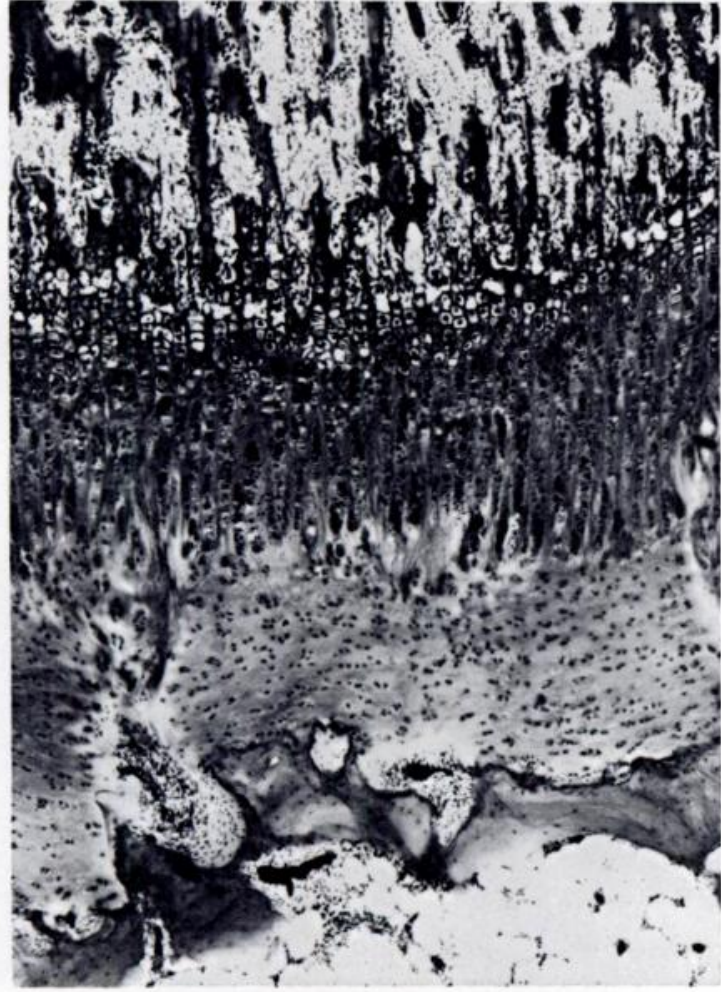

Fig. 7

Female, 16 months. Growth cartilage from Figure 6 (Haematoxylin and eosin, $\times 44$.)

even absent (Fig. 4), but by about twelve months of age the plate has taken on its characteristic appearance as a transverse band of cartilage between the metaphysis and the epiphysial centre of ossification. On the metaphysial aspect of the plate there is a zone (the "columnar zone")

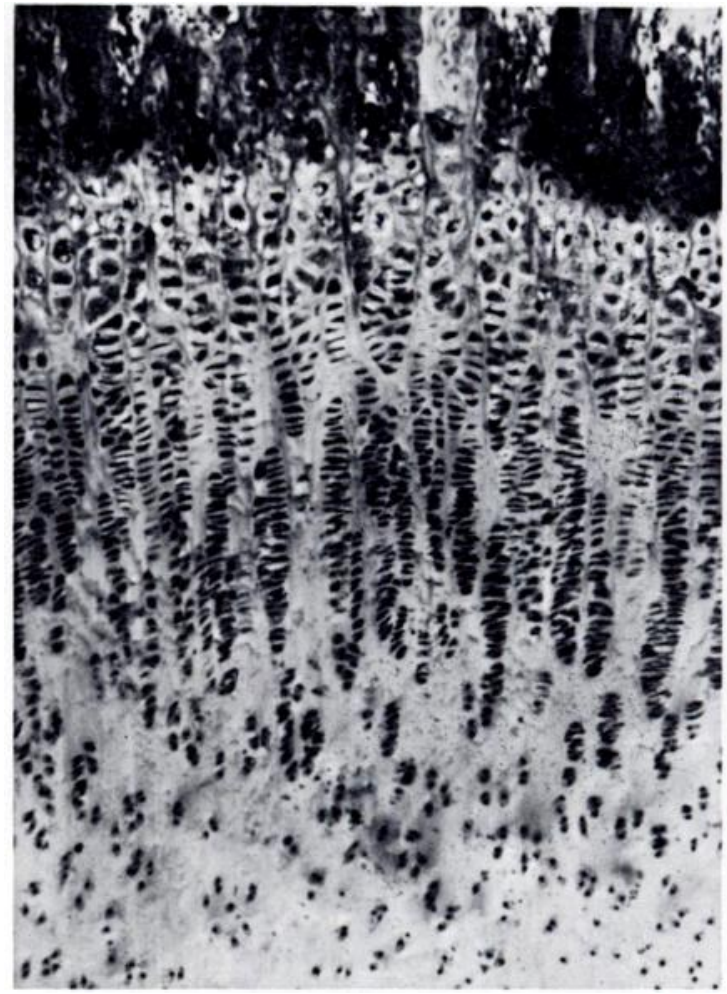

Fig. 8

Male, aged $3 \frac{1}{2}$ years. Columnar part of growth cartilage from lower end of femur. (Haematoxylin and eosin, $\times 90$.)

line of the columns. We refer to this region of the plate as the "inert zone" as it appears to make no contribution to the longitudinal growth of the bone. Within the columnar zone, particular regions can be identified (Figs. 8 and 11 ). Some sections show small cell clusters at the 


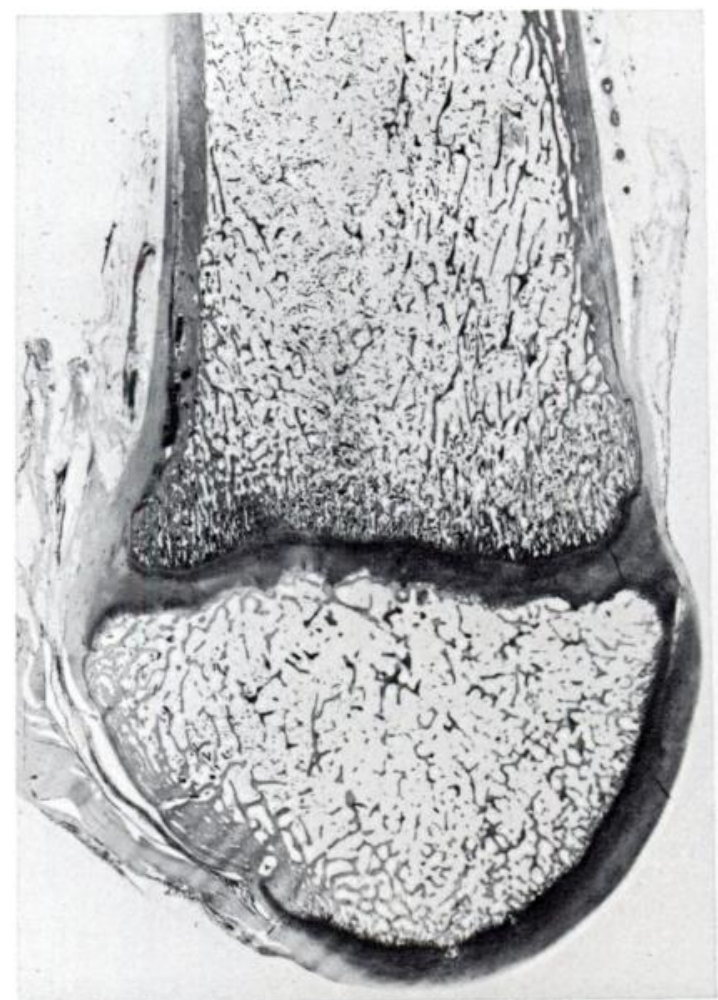

Fig. 9

Male, 7 years. Longitudinal section through lower end of femur. (Haematoxylin and eosin, $\times 22$.)

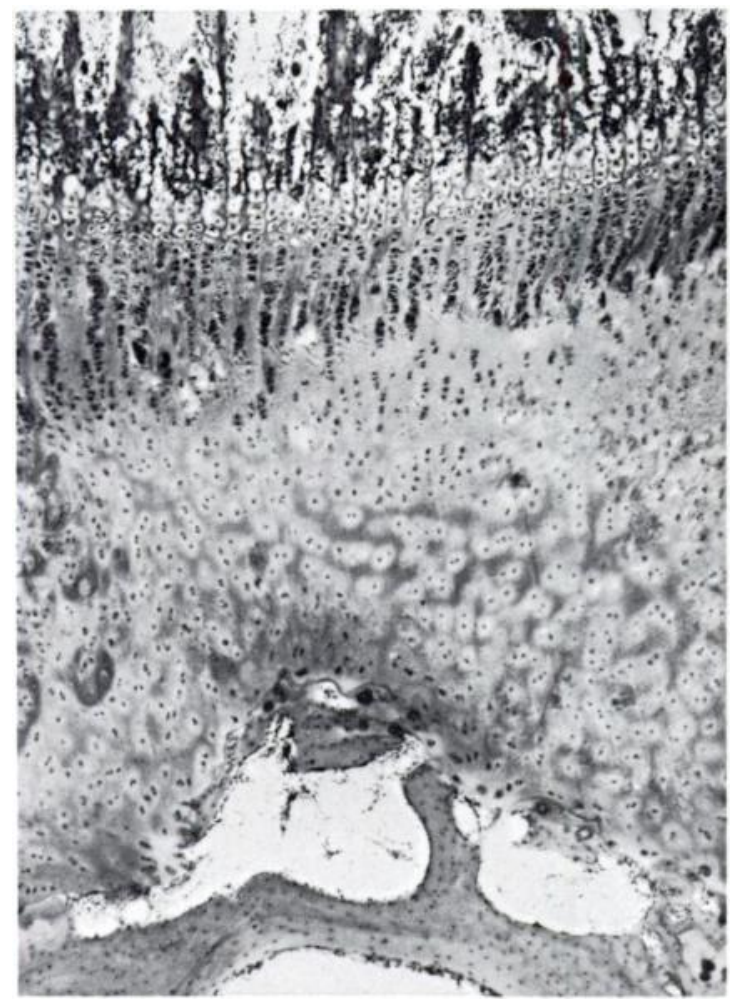

Fig. 10

Male, 7 years. Growth cartilage from Figure 9. (Haematoxylin and eosin, $\times 44$.)

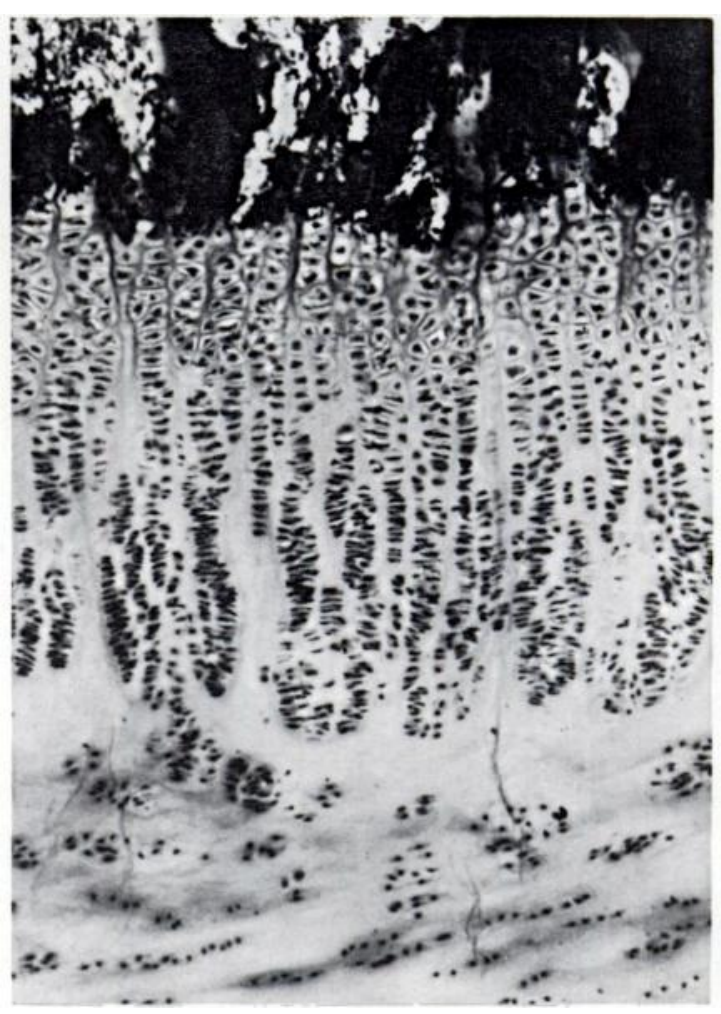

Fig. 11

Male, 8 years. Columnar part of growth cartilage from lower end of femur. (Haematoxylin and eosin, $\times 90$.) 
epiphysial ends of the columns and adjacent to these a region of flattened cells that are probably the proliferating cells. Passing along the columns towards the metaphysis there are the rounded cells of the maturation zone and plate, which begins when the growth spurt has finished. Figures 12 and 13 show the plate from a girl aged fourteen where growth may be presumed to be much less active, and where this is reflected in the changed appearance of

TABLE I

Summary of Quantitative Histology (Mean Values)

\begin{tabular}{|c|c|c|c|c|c|c|}
\hline $\begin{array}{c}\text { Age } \\
\text { (years) }\end{array}$ & Sex & $\begin{array}{c}\text { Maturing and } \\
\text { proliferating } \\
\text { cells }\end{array}$ & $\begin{array}{c}\text { Hypertrophic } \\
\text { cells }\end{array}$ & $\begin{array}{c}\text { Hypertrophic } \\
\text { cell height } \\
(\mu m)\end{array}$ & $\begin{array}{c}\text { Width of } \\
\text { inert zone } \\
\text { (millimetres) }\end{array}$ & $\begin{array}{c}\text { Width of } \\
\text { columnar zone } \\
\text { (millimetres) }\end{array}$ \\
\hline 0 & Male & 62 & 12 & 35 & - & 0.9 \\
0.9 & Male & 43 & 8 & 38 & 0.8 & 0.7 \\
1.3 & Female & 46 & 8 & 34 & 0.6 & 0.8 \\
2 & Male & 49 & 6 & 30 & 0.9 & 0.7 \\
2 & Male & 48 & 8 & 35 & 0.8 & 0.7 \\
3.5 & Male & 54 & 7 & 38 & 1.1 & 0.8 \\
5 & Male & 36 & 6 & 33 & 1.0 & 0.6 \\
7 & Male & 36 & 7 & 37 & 1.2 & 0.6 \\
8 & Male & 34 & 8 & 29 & 0.5 & 0.5 \\
13 & Male & 27 & 5 & 30 & 0.8 & 0.5 \\
14 & Male & 28 & 6 & 39 & 0.7 & 0.5 \\
14 & Female & 21 & 2 & 25 & 0.1 & 0.4 \\
\hline
\end{tabular}

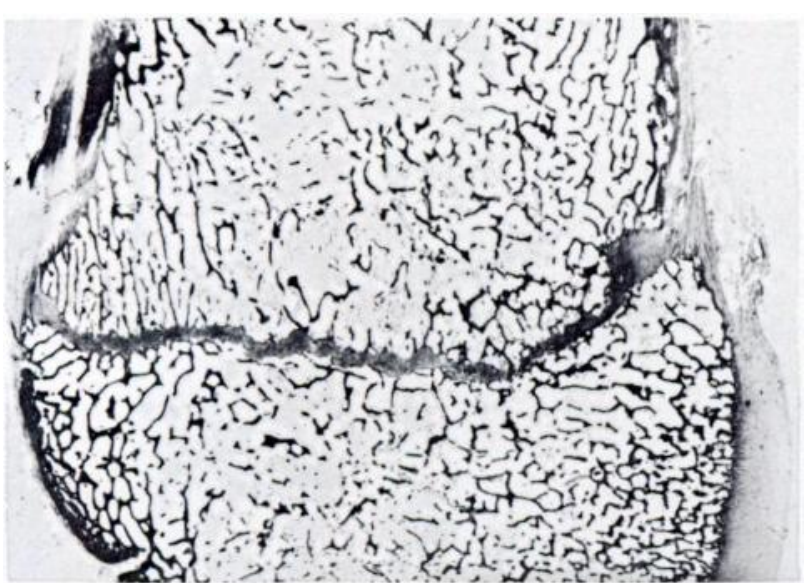

FIG. 12

Female, 14 years. Longitudinal section through lower end of femur. (Haematoxylin and eosin, $\times 2.5$.)

FIG. 13

Female, 14 years. Growth cartilage from Figure 12. (Haematoxylin and eosın, $\times 44$.)

then the typical hypertrophic cells with degenerate nuclei.

As seen in Figures 6 to 11, the general appearance of the plate does not change substantially during the years before the process of "closure" or "fusion" of the

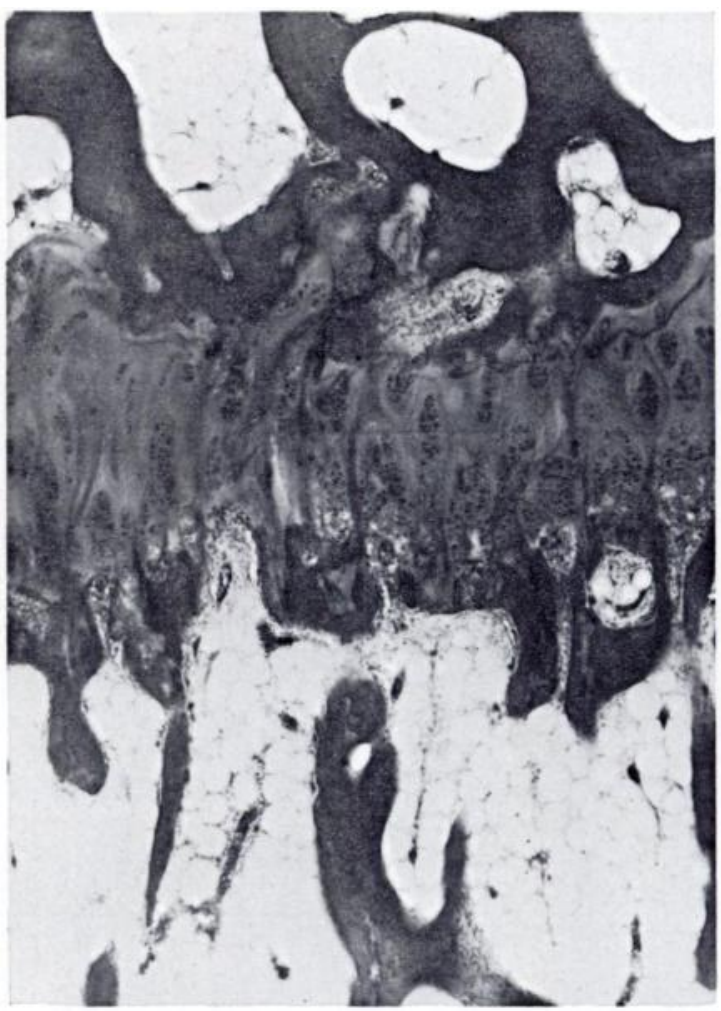

Fig. 13

the plate. The plate is thinner than at earlier ages, and there is evidence of cartilage degeneration in some areas with loss of cells. The inert zone of the plate has largely disappeared, and the cell columns have been replaced by 
rounded clusters of cartilage cells. The general appearance of this plate is similar to that described by Haines (1975) at the time of epiphysial closure.
There is, of course, a rich network of capillary blood vessels on the metaphysial surface of the plate, where endochondral ossification is occurring. A smaller number
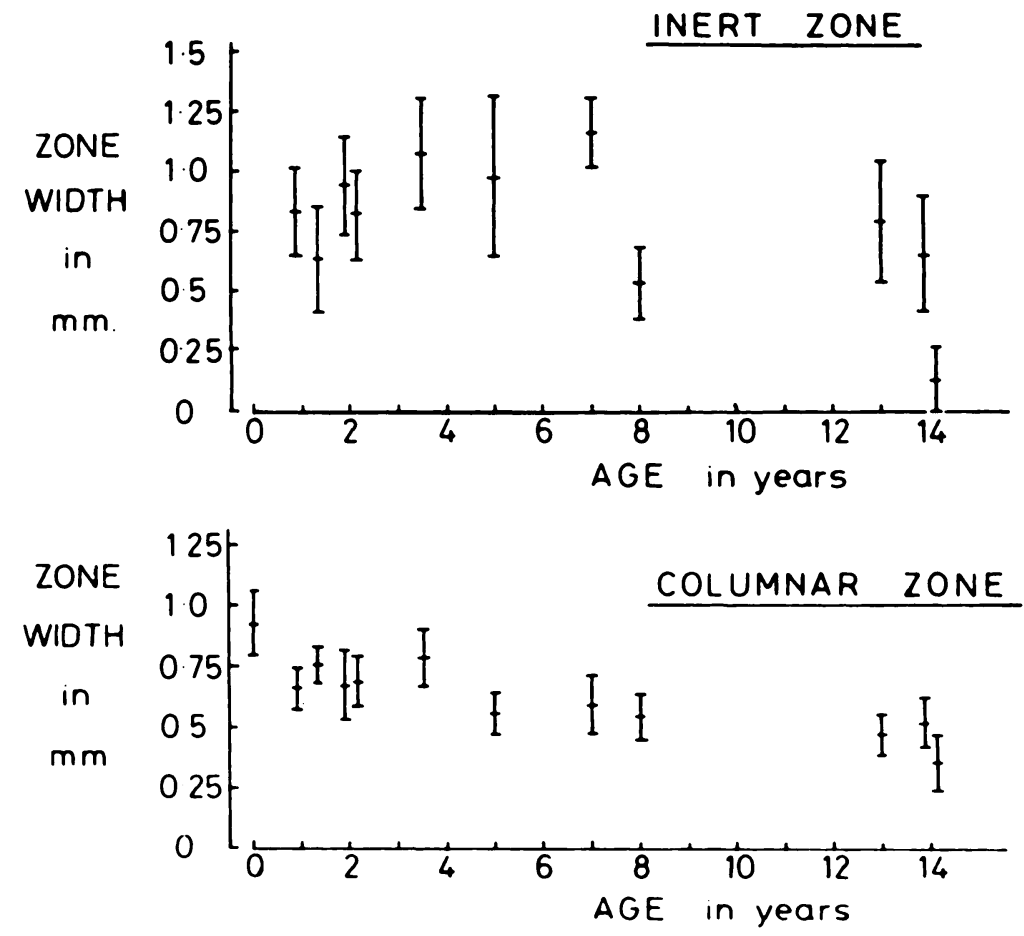

Fig. 14

Thickness of inert and columnar zones of distal plate of femur in all cases studied.
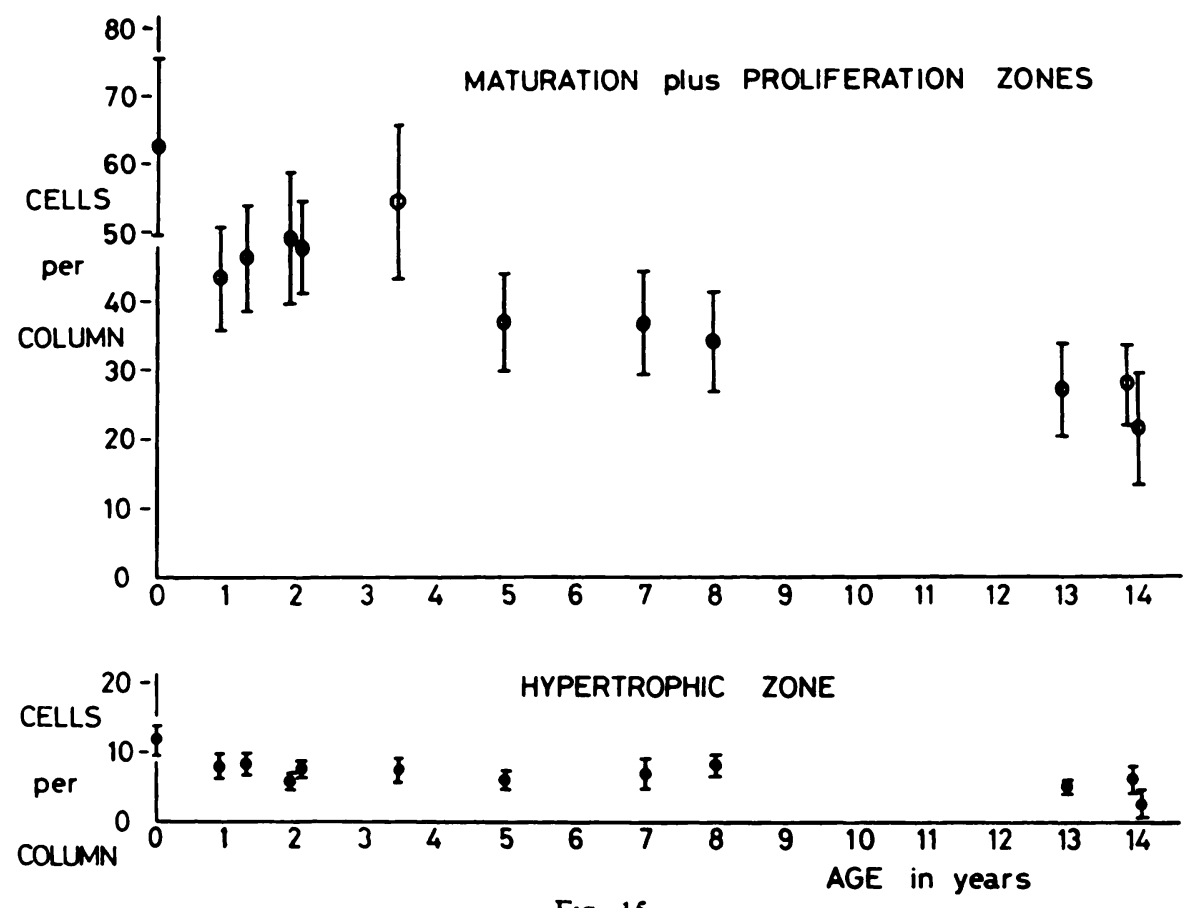

Fig. 15

Cell numbers in the different zones of the columnar part of the distal plate of femur in all cases studied.

Some observations on the blood supply of the developing human growth plate may be of interest, as there is little or no information on this subject in the literature. of somewhat larger vessels are present, at all ages, in the epiphysis adjacent to the layer of bone which covers the epiphysial surface of the plate (Fig. 7). In the youngest 
specimens, penetrating blood vessels ("cartilage canals") were seen in the cartilage of the epiphysis itself (Fig. 4). From one year onward, when the growth plate was an anatomically defined structure, penetrating blood vessels were occasionally seen in the plate itself (Fig. 7), although only one or two of these structures could usually be found in any one section.

\section{Quantitative histology}

The results for the measurements of the overall widths of the inert and columnar zones in each of the cases studied are shown in Figure 14 and in Table I. In Figure 14 each bar shows the mean and standard deviation for the sequence of measurements made across the plate. The results show that once the secondary centre of ossification is established there is little change in the relative widths of the inert and columnar zones until closure of the plate occurs.

The mean heights of hypertrophic cells, from birth to thirteen years of age, were all within the range 29 to $38 \mu \mathrm{m}$, and there was no evidence of age dependence. For the age range five to eight years, the mean value was $33 \pm 5 \mu \mathrm{m}$. For the two fourteen-year-old specimens the values were $39 \mu \mathrm{m}$ for the male and $25 \mu \mathrm{m}$ for the female, with plate closure in progress.

The results for the numbers of cartilage cells in the columns are shown in Figure 15 and in Table I. In columns of about the same length as in the human. In the rabbit, the proliferation zone contains about twice the number of cells as the maturation zone, and we have therefore assumed that the number of proliferating cells in the human growth plates is approximately two-thirds of the figure for proliferating and maturing cells in Table I.

Making this assumption, the results we have obtained can be used to estimate the mean cell cycle time for the cartilage cells of the proliferation zone of the plate. The mean cell cycle time is equal to the number of proliferating cells per column divided by the rate of new cell production (Kember 1972), and this can be obtained from the observed growth rate of the plate and the mean height of hypertrophic cells in the columns (Sissons 1956).

Since the measured variation in growth rate is least in the period from five to ten years of age, the most reliable estimate of cell cycle time will be based on our findings in the specimens during this period (that is, the five-, seven- and eight-year-old specimens). The results are shown in Table II.

For the five- to eight-year period the growth rate for the distal femur is 1.4 centimetres per year ( $38 \mu \mathrm{m}$ per day). Thus the average rate of production of new cells in each column is 1.2 per day. At this stage the number of cells in the combined maturation and proliferation zones is thirty-six, so the estimated numbers of cells for the

TABLE II

Values Used in Estimation of Cell Cycle Time

\begin{tabular}{|c|c|c|c|c|c|c|c|}
\hline \multirow{2}{*}{$\begin{array}{c}\text { Age range } \\
\text { (years) }\end{array}$} & \multicolumn{2}{|c|}{ Growth rate } & \multirow{2}{*}{$\begin{array}{c}\text { Hypertrophic } \\
\text { cell height } \\
(\mu m)\end{array}$} & \multirow{2}{*}{$\begin{array}{l}\text { New cells } \\
\text { per day }\end{array}$} & \multirow{2}{*}{$\begin{array}{l}\text { Number of cells } \\
\text { mature and } \\
\text { proliferating }\end{array}$} & \multirow{2}{*}{$\begin{array}{l}\text { Number of cells } \\
\text { proliferating }\end{array}$} & \multirow{2}{*}{$\begin{array}{c}\text { Cell cycle } \\
\text { time } \\
\text { (days) }\end{array}$} \\
\hline & $(\mathrm{cm} /$ year $)$ & $(\mu m / d a y)$ & & & & & \\
\hline $5-8$ & 1.4 & 38 & 33 & $1 \cdot 2$ & 36 & 24 & 20 \\
\hline $3 \frac{1}{2}$ & $1 \cdot 6$ & 44 & 38 & $1 \cdot 2$ & 54 & 36 & (30) \\
\hline 2 & $(2 \cdot 0)$ & 55 & 33 & $1 \cdot 7$ & 48 & 32 & (20) \\
\hline
\end{tabular}

Figure 15 the number of hypertrophic cells in each column shows some decrease with age but in parallel with the number of cells in the maturation and proliferation zones there is no marked decline until the plate closes.

In order to make an estimate of the rate of cell division for the cartilage cells it is necessary to know the number of cells which are specifically within the proliferation zone. In work with experimental animals (Kember 1972) this is normally found by plotting the positions of labelled cells in autoradiographs from animals which have received tritiated thymidine. There are, unfortunately, no precise morphological criteria for distinguishing between proliferating and maturing cells at the boundary between these two zones in a stained section. It is possible, however, to use the data in Table I to make an estimate of the number of cells in the proliferative zone by means of a comparison with the growth plate of the rabbit, which, although it has no inert zone, has cartilage proliferation zone is twenty-four. Since these cells produce 1.2 new cells each day, they must each divide about once every twenty days, which is thus the cell cycle time.

Using the same procedure but less reliable data (Table II), at two years of age a cell cycle time of twenty days is estimated and at three and a half years a value of thirty days. No estimate can be made for the thirteenand fourteen-year-old specimens because of the widely differing rates of growth in different individuals during and after the growth spurt.

\section{DISCUSSION}

Most of the published information on longitudinal bone growth in normal children (Anderson and Green 1948; Maresh 1970) is limited to overall values for entire bones, and does not identify the contribution that is made by an individual growth plate as in the present study. In 
the study from which our own growth information was obtained, radiographs of the femur were limited to the lower part of the bone, and it was therefore impossible to determine the proportion of the total growth of the femur which was contributed by the distal growth plate. Comparison of our data with the measurements of Maresh (1970) for the overall length of the femur in normal American children, where a growth rate of approximately 2.2 centimetres/year was obtained between five and eight years of age, suggests that the growth at the lower end of the femur accounts for approximately two-thirds of the total growth of the bone. Anderson, Green and Messner (1963), in order to predict the shortening following epiphysial arrest, used, as we have done, radiographs with lines of temporary growth arrest to estimate the

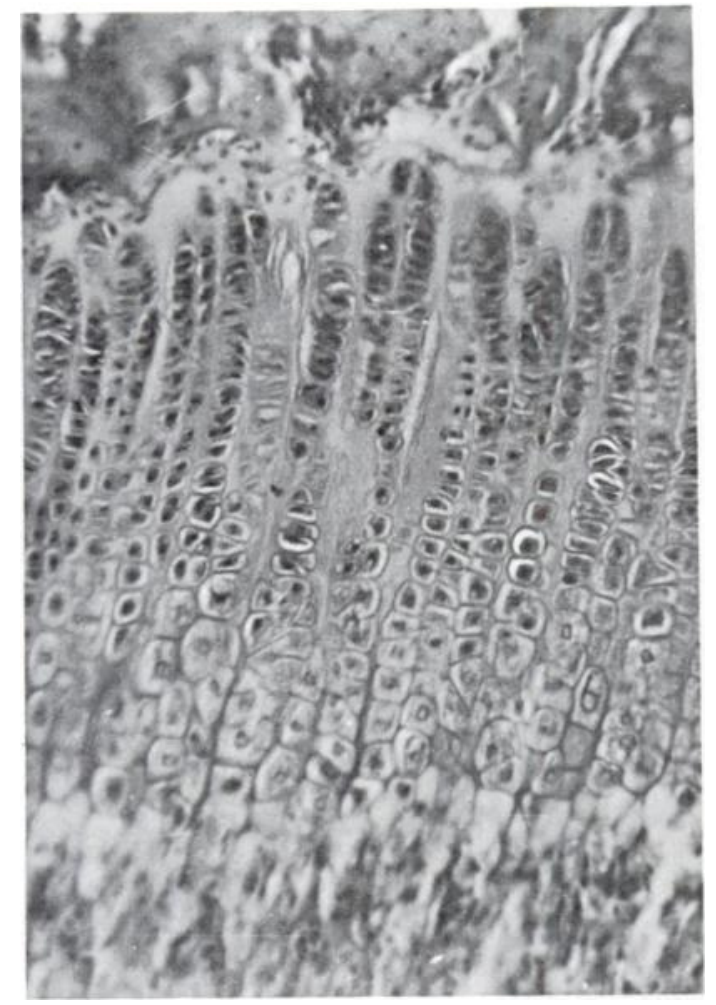

Fig. 16

Rat, 6 weeks. Growth cartilage of tibia. $(\times 200$. $)$

growth occurring at the lower end of the femur. They concluded that, on the average, 71 per cent of the total growth of the femur occurred at the lower end.

Most of the published information on the histological structure, blood supply and cell cycle time for the growth plates of mammalian long bones relates to mice, rats and rabbits, as these are the animals that have most often been used in investigations of bone growth. The results of the present study make it clear that there are major differences between the growth plates of these small rodents and that of man. In rodents, after the appearance of the secondary centre of ossification and the development of the epiphysial bone plate, the epiphysial aspect of the growth plate shows a narrow zone of cartilage, adjacent to the end of the cartilage columns and thus comparable to the wider "inert zone" of cartilage which we have found to be present in man. The appearance of the young rodent plate is shown in Figure 16, from a rat aged six weeks. Another important difference is, of course, that in many rodent species such as the rat, closure of the growth plates does not occur; the plates persist as inactive structures after the cessation of longitudinal growth. In man, the "inert zone" is a feature of the growth plate throughout the entire growth period. The precise function of the inert zone is not clear. It cannot be a "reserve" zone of stem cells for the cartilage plate, since it does not become thinner or disappear as growth proceeds (Haines and Mohiuddin 1959). In early childhood, it is anatomically continuous with the cartilage of the epiphysis deep to the articular cartilage, and has a similar histological appearance to this tissue. It is seen in other primates (Reith and Ross 1970): its function may well be mechanical.

The presence of this inert zone of cartilage on the epiphysial aspect of the growth plate in man suggests that the vascular supply of the proliferation zone of the plate may be different from what has sometimes been suggested on the basis of the rodent plate. In animals such as rats and rabbits the nourishment and respiratory exchange of the proliferating cells of the growth plate appears to be derived from the adjacent vessels of the epiphysis (Trueta 1963), whereas in man the inert zone of the growth cartilage is interposed between these cells and the epiphysial vessels. It might therefore be expected that the concentration of oxygen and other metabolites in the cells of the proliferation zone of the human growth plate would be lower than in small rodents, or that the respiratory exchange and nutrition of these cells is derived from the metaphysial vessels.

Our estimate for the mean cell cycle time for the proliferating cells of the human growth cartilage at the distal end of the femur is twenty days for the ages of five to eight years. The largest uncertainty in this estimate appears to relate to the value for the number of cells in the proliferation zone of the cartilage columns. It is unlikely, however, that there are less than twenty cells in the proliferation zone at this age, and this would correspond to a lower limit of approximately sixteen days for the mean cell cycle time. During the growth spurt there is no evidence that the number of cells in the proliferation zone increases, and it thus seems likely that the proliferating cells divide faster in order to produce the increased growth rate.

It is clear that in comparison with rodents, the human growth plate grows slowly, and the rate of cell division in the proliferating cells of the cartilage columns is low. In a young rat, for example, the growth rate is approximately $200 \mu \mathrm{m}$ per day (human of five to eight years, $35 \mu \mathrm{m}$ per day) and the cell cycle time is two days (human of five to eight years, twenty days). The much greater length of the human femur is due, of course, to the much longer period of growth in man than in the rat.

Although the average cell cycle time, in our material, 
is approximately twenty days, it is probable that some cells in the proliferating zone are dividing faster than this. Studies with rat tibiae using the technique of continuous labelling with tritiated thymidine (Walker and Kember 1972) show a relatively rapid rate of division for cells in the central part of the proliferation zone (50 to 60 per cent of cells dividing every day), while the cells at the epiphysial end of the columns are dividing more slowly ( 5 to 10 per cent each day). Similarly in the human growth plate some cells might divide every ten days while others at the epiphysial ends of the columns might be dividing only once every 100 days. Information on this variation in the relative rates of division of cells in different parts of the proliferation zone could be obtained in fresh material by studying the relative frequency of mitotic cells in different parts of the column, either in stained sections or by means of labelling with tritiated thymidine after in vitro incubation.

We are indebted to Professor J. M. Tanner and his colleagues in the Department of Growth and Development at the Institute of Child Health for making available to us the radiographs of children from the Harpenden Growth Study from which our measurements of growth rates were made.

\section{REFERENCES}

Anderson, M., and Green, W. T. (1948) Lengths of the femur and the tibia. Norms derived from orthoroentgenograms of children from 5 years of age until epiphysial closure. American Journal of Diseases of Children, 75, 279-290.

Anderson, M., Green, W. T., and Messner, M. B. (1943) Growth and predictions of growth in the lower extremities. Journal of Bone and Joint Surgery, 45-A, 1-14.

Haines, R. W. (1975) The histology of epiphyseal union in mammals. Journal of Anatomy, 120, 1-25.

Haines, R. W., and Mohiuddin, A. (1959) A preliminary note on the process of epiphyseal union. Journal of the Faculty of Medicine, Baghdad, N.S. 1, 141-147.

Harris, H. A. (1933) Bone Growth in Health and Disease. London: Oxford University Press.

Kember, N. F. (1972) Comparative patterns of cell division in epiphyseal cartilage plates in the rat. Journal of Anatomy, 111, $137-142$.

Kember, N. F. (1973) Patterns of cell division in the growth plates of the rat pelvis. Journal of Anatomy, 116, 445-452.

Maresh, M. M. (1970) Measurements from roentgenograms: heart size, long bone lengths, bone muscle and fat widths, skeletal maturation. In Human Growth and Development, Section F, pp. 157-200. Edited by R. W. McCammon. Springfield, Illinois: Charles C. Thomas.

Rang, M. C. (1969) The Growth Plate and its Disorders. Edinburgh and London: E. \& S. Livingstone.

Reith, E. J., and Ross, M. H. (1970) Atlas of Descriptive Histology. Second edition. New York: Harper and Row.

Sissons, H. A. (1956) Experimental study of the effect of local irradiation on bone growth. In Progress in Radiobiology, pp. 436-448. Edited by J. S. Mitchell, B. E. Holmes and C. L. Smith. Edinburgh: Oliver and Boyd.

Sissons, H. A. (1971) The growth of bone. In The Biochemistry and Physiology of Bone. Volume 3, second edition, Chapter 4, pp. 145-180. Edited by G. H. Bourne. New York and London: Academic Press.

Tanner, J. M., Whitehouse, R. H., and Takaishi, M. (1966) Standards from birth to maturity for height, weight, height velocity, and weight velocity: Britısh chıldren, 1965. Archives of Disease in Childhood, 41, 454-471, 613-635.

Trueta, J. (1963) The role of the vessels in osteogenesis. Journal of Bone and Joint Surgery, 45-D, 402-418.

Walker, K. V. R., and Kember, N. F. (1972) Cell kinetics of growth cartilage in the rat tibia. II. Measurements during ageing. Ce!l and Tissue Kinetics, 5, 409-419. 